\title{
Pelatihan pembuatan desinfektan yang aman dan ramah lingkungan di Wilayah Awipari sebagai upaya pencegahan penyebaran Covid-19
}

\section{Puji Lestari ${ }^{1}$, Nani Ratnaningsih ${ }^{2}$, Diar Veni Rahayu ${ }^{3}$, Mega Prani Ningsih ${ }^{4}$}

\author{
1,2,3 Dosen Pendidikan Matematika, Program Pascasarjana, Universitas Siliwangi \\ ${ }^{4}$ Pendidikan Geografi, FKIP, Universitas Siliwangi \\ pujilestari@unsil.ac.id
}

\begin{abstract}
This community service activity is motivated by the potential for the spread of the Covid virus which is still happening and the Awipari Village does not yet have health facilities that are balanced with its population. In addition, the use of disinfectants as a protection for families and the environment from the spread of the Covid-19 virus is still not available with natural ingredients and is safe for the environment. This is what training on the manufacture of safe and environmentally friendly disinfectants needs to be done. The main purpose of this community service is to help target partners to be more independent in providing the disinfectant needs that residents need. Furthermore, it can be used as an alternative field to increase household income. The specific target to be achieved in the future is that target partners are able and accustomed to using safe and environmentally friendly basic materials in making disinfectants. Community service activities will be held in September 2021 at the Awipari Village Office, Tasikmalaya City. The methods used are lectures, discussions, and the practice of making disinfectants directly. Community service activities are very well received by partner community groups. The community is enthusiastic and active in demonstrations and discussions and wants this service activity to be routine and continue with various training themes according to community needs.
\end{abstract}

Keywords: covid-19; natural disinfectant; training; manufacture of disinfectant

\begin{abstract}
Abstrak
Kegiatan pengabdian kepada masyarakat ini dilatarbelakangi oleh potensi persebaran virus Covid yang masih terjadi dan Kelurahan Awipari belum memiliki fasilitas kesehatan yang berimbang dengan jumlah penduduknya. Selain itu, pemanfaatan disinfektan sebagai perlindungan keluarga dan lingkungan dari persebaran virus Covid-19 masih belum ada yang berbahan alami dan aman terhadap lingkungan. Hal inilah yang mendasari perlu dilakukan pelatihan pembuatan disinfektan yang aman dan ramah lingkungan. Tujuan utama kegiatan pengabdian masyarakat ini untuk membantu mitra sasaran supaya lebih mandiri dalam menyediakan kebutuhan desinfektan yang diperlukan warga. Lebih lanjut, mampu menjadikannya sebagai ladang alternatif untuk menambah pendapatan rumah tangga. Target khusus yang hendak dicapai dimasa depan yaitu mitra sasaran mampu dan terbiasa memanfaatkan bahan dasar yang aman dan ramah lingkungan dalam membuat desinfektan. Kegiatan pengabdian kepada masyrakat dilaksanakan pada bulan September 2021 bertempat di Kantor Kelurahan Awipari, Kota Tasikmalaya. Metode yang digunakan yaitu ceramah, diskusi dan praktek pembuatan disinfektan secara langsung. Kegiatan pengabdian kepada masyarakat diterima dengan sangat baik oleh kelompok masyarakat mitra. Masyarakat antusias dan aktif pada kegiatan demo dan diskusi serta menginginkan kegiatan pengabdian ini dapat rutin dan berlanjut dengan tema-tema pelatihan yang bervariasi sesuai kebutuhan masyarakat.
\end{abstract}

Kata Kunci: covid-19; disinfektan alami; pelatihan; pembuatan disinfektan 


\section{PENDAHULUAN}

Pemerintah mengkonfirmasi masuknya wabah Covid-19 ke Indonesia pertama kali pada 2 Maret 2020 (Nursofwa, Sukur, \& Kurniad, 2020). Ini berawal dari adanya kasus yang terkonfirmasi positif muncul. Virus COVID-19 ini diperkirakan menyebar terutama dari orang ke orang, terutama melalui pernapasan percikan ketika orang yang terinfeksi batuk atau bersin. Percikan ini dapat mendarat di mulut atau hidung orang-orang yang berada di dekatnya atau mungkin terhirup ke dalam paru-paru. Transmisi lain virus corona, seperti kontak dengan yang terkontaminasi dan inhalasi aerosol. (Ertiyana, Ulfa, Aspiyani, Silaturrokhmah, \& Prastiwi, 2020).

Menurut Wang (2020) virus corona bersifat sangat sensitive terhadap panas dan secara efektif dapat dinon aktifkan oleh desinfektan mengandung klorin, pelarut lipid dengan suhu $56^{\circ} \mathrm{C}$ selama 30 menit, eter, alkohol, asam perioksiasetat, detergen non-ionik, formalin, oxidizing agent dan kloroform. Klorheksidin tidak efektif dalam menonaktifkan virus. Setiap pandemi yang terjadi diberbagai belahan dunia dan periode waktu tertentu selalu menimbulkan korban jiwa yang besar.

Masyarakat berpotensi terinveksi virus Covid-19 dan menjadi korban dari persebaran virus ini. Salah satunya adalah masyarakat di wilayah Kelurahan Awipari. Kelurahan Awipari merupakan salah satu kelurahan di Kecamatan Cibeureum, Kota Tasikmalaya, Provinsi Jawa Barat. Kelurahan Awipari memiliki luas wilayah sekitar 1468 km² (https://tasikmalayakota.bps.go.id). Kelurahan ini memiliki $6 \mathrm{RW}$ dan $30 \mathrm{RT}$ dengan jumlah penduduk sebanyak 5.373 orang dan terdiri dari 1.655 KK (Kepala Keluarga). Sebagai kelurahan yang memiliki banyak penduduk, ketersediaan sarana prasarana kesehatan belum berimbang dengan jumlah penduduk.

Fasilitas kesehatan seperti Puskesmas atau Puskesmas pembantu belum tersedia di Kelurahan Awipari. Kondisi ini mungkinkan munculnya permasalahan terkait kesehatan, terutama terkait penyebaran virus Covid-19 di lingkungan Kelurahan Awipari. Jumlah kasus terkonfirmasi positif di wilayah Kelurahan Awipari ada dua $\begin{array}{lllllll}\text { Kasus } & \text { per } & 5 & \text { Agustus } 2020 & \text { berjumlah } & 2 & \text { kasus }\end{array}$ (https://pikobar.jabarprov.go.id/distribution-case). Meskipun demikian, kasus ini perlu menjadi perhatian mengingat varian Covid-19 yang makin berkembang dan mengakibatkan penyebaran yang sangat masif.

Bebagai upaya telah dilakukan baik oleh pemerintah maupun masyarakat secara umum melalui pendampingan pihak eksternal melalui bentuk program-program kegiatan. Kegiatan ini diupayahkan melalui berbagai strategi untuk menekan penyebaran virus Covid-19. Namun hasil dari kegiatan tersebut dirasa belum terlalu optimal dalam mencegah penyebarn virus Covid-19. Upaya nyata yang bisa dilakukan untuk mencegah penyebaran virus diantaranya menginisiasi warga dan lingkungan untuk menjalankan protokol kesehatan. 
Bagi warga di wilayah Kelurahan Awipari, kegiatan penyuluhan mengenai protokol kesehatan sudah beberapa kali dilakukan yang disponsori oleh pihak eksternal, sehingga warga cukup teredukasi dalam hal protokol kesehatan. Penyuluhan tentang $5 \mathrm{M}$, peringatan yang ditulisan dalam Spanduk juga sudah dilakukan. Hal lain yang juga sudah terlaksana yaitu proses kegiatan penyemprotan desinfektan di lingkungan tempat tinggal warga. Dengan bantuan berbagai pihak instansi.

Namun kegiatan penyemprotan desinfektan tidak dapat dilakukan secara kontinu karena bergantung pada bantuan dari pihak eksternal. Selain itu, selama ini produk desinfektan yang digunakan masih banyak yang mengandung bahan kimia sehingga tidak cukup aman dan ramah lingkungan. Dengan demikian untuk dapat menjadikan kegiatan penyemprotan desinfektan secara kontinu serta penyediaan desinfektan yang aman dan ramah lingkungan, masih terkendala.

Kondisi ini menjadi alasan utama bagi kami selaku pihak eksternal untuk melihat peluang melaksanakan kegiatan Pengabdian Kepada Masyarakat (PKM) terkait penyediaan disinfektan yang aman dan ramah lingkungan. Disinfektan adalah senyawa kimia yang mampu membunuh virus dengan jalan masuk menembus dinding virus dan akan merusak bagian dalam virus (Indrawati, 2020). Bahan dasar disinfektan yang merupakan bahan alami cukup mudah diperoleh di lingkungan sekitar. Biaya pembuatannya masih bisa dijangkau oleh masyarakat sebagai upayah pencegahan penyebaran Covid-19. Bahan dasar yang sering digunakan yaitu, sirih (Piper betle L.) dan jeruk nipis (Citrus aurantiifolia).

Salah satu bahan dasar alami pembuatan disinfektan adalah daun serai. Hariani, Said, dan Rohendi (2021) menyatakan bahwa pembuatan disinfektan dapat dibuat dengan penambahan aroma alami ekstrak daun serai. Ekstrak daun serai bersifat antibakteri, antiseptik dan memiliki aroma yang segar. Selain itu, kegiatan PKM yang dilakukan Dharmawanti, Aprillia, Rahmawati, Alfiah, dan Pujiyant (2021), menggunakan bahan lain jeruk nipis yang dinilai efektif dan aman sebagai bahan pembuatan disinfektan. Penelitian Budiman, Arisman, Sulfidar, dan Arsyad (2020) menunjukkan bahwa mencampurkan daun sirih dan jeruk nipis sebagai bahan dasar pembuatan disinfektan dinilai bermanfaat mengatasi bakteri-bakteri. Penggunaan bahan dasar tersebut memberikan kemudahan dalam hal dana sebab pengeluaran dana cukup minim tetapi dapat menjadi alternatif pencegahan penularan virus Covid-19.

Kegiatan Pengabdian Kepada Masyarakat ini dilakukan dengan memanfaatkan bahan dasar yang lebih beragam. Bahan dasar tersebut tentunya bersifat alami dan aman terhadap lingkungan. Selain daun sirih dan jeruh nipis, pelatihan ini memanfaatkan bahan lain yang mudah di dapat. Bahan-bahan alami tersebut diantaranya, lidah buaya (Aloe vera), lemon (Citrus limon), kulit rambutan (Nephelium lappaceum), serai (Cymbopogon citratus), dan cuka putih. Kegiatan dilakukan dengan mempraktekkan secara langsung proses pembuatan disinfektan dengan bahan-bahan alami tersebut. 
Namun kami juga menyadari perlu adanya peran dan partisipasi masyarakat di wilayah Awipari untuk bersama-sama berkoordinasi mengatasi permasalahan Covid-19 yang sedang dihadapi bersama. Dengan demikian kegiatan pelatihan ini mengajak dua mitra yang berpotensi untuk menyebarkan ilmu pelatihan yang telah peroleh secara lebih luas ke lingkungan Kelurahan Awipari. Sasaran mitra kegiatan ini adalah pengurus Karang Taruna Awipari dan RW Talangsari (RW. 01), Kelurahan Awipari, Kecamatan Cibereum, Kota Tasikmalaya yang dapat membantu kami untuk berkoordinasi dengan maksimal dalam kegiatan ini. Dengan demikian peran serta masarakat dapat membantu dalam menekan penyebaran virus Covid-19 khususnya di Kelurahan Awipari, Kecamatan Cibereum, Kota Tasikmalaya

Tujuan utama kegiatan pengabdian masyarakat ini adalah untuk membantu mitra sasaran supaya lebih mandiri dalam menyediakan kebutuhan desinfektan yang diperlukan warga. Bahkan mampu menjadikannya sebagai ladang alternatif untuk menambah pendapatan rumah tangga. Adapun target khusus yang hendak dicapai dimasa depan yaitu mitra sasaran mampu dan terbiasa memanfaatkan bahan dasar yang aman dan ramah lingkungan dalam membuat desinfektan.

\section{METODE PELAKSANAAN}

Kegiatan PKM dengan Skema Kesehatan(PbM-SK) dilakukan di wilayah Awipari dengan mitra yaitu pengurus Karang Taruna Awipari dan RW Talangsari (RW. 01), Kelurahan Awipari, Kecamatan Cibereum, Kota Tasikmalaya. Metode yang digunakan adalah melalui pendampingan dan pemberdayaan. Pendampingan dan pemberdayaan masyarakat dapat diartikan sebagai bentuk kegiatan untuk menumbuhkan inisiatif masyarakat sehingga dapat lebih berpartisipasi dalam memulai kegiatan sosial. Hal ini bertujuan untuk memperbaiki situasi dan kondisi diri sendiri, keluarga dan lingkungan (LPPM UBHI dalam Hairunisya dkk, 2020).

Pelaksanaan dilakukan melalui pendekatan kelompok dan partisipatif. Hal ini diwujudkan melalui metode penyampaian materi mealui metode ceramah, tanya jawab dan diskusi dan demo/praktek. Prosedur kegiatan Pengabdian Kepada Masyarakat ini dilakukan dengan tiga tahapan, yaitu tahap persiapan, tahap pelaksanaa dan tahap evaluasi seperti pada gambar berikut.

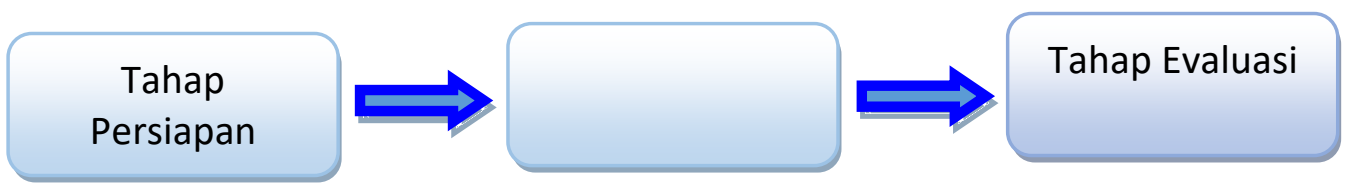

Gambar 1. Tahap Pelaksanaan Kegiatan PKM

Lebih rinci, kegiatan yang dilakukan pada setiap kegiatan adalah sebagai berikut.

1. Menentukan permasalahan dan mitra pengabdian kepada masyarakat sesuai tema yang diusung.

2. Sosialisasi dengan kelompok mitra terkait kegiatan pelatihan yang akan dilakukan.

3. Menyusun pedoman pelatihan. 
4. Menyiapkan sarana dan prasarana kegiatan pelatihan

5. Melakukan kegiatan pendampingan kepada kelompok mitra dengan ceramah, diskusi dan demo/praktek.

6. Melakukan evaluasi kegiatan melalui angket evaluasi kegiatan.

\section{HASIL DAN PEMBAHASAN}

Kegiatan Pengabdian Kepada Masyarakat yang dilakukan sudah sesuai dengan tema yang diusung dan sesuai dengan tahapan mulai dari persiapan hingga evaluasi. Pelaksanaan Pelatihan Pembuatan Desinfektan Yang Aman Dan Ramah Lingkungan Di Wilayah Awipari Sebagai Upaya Pencegahan Penyebaran Covid-19 dilaksanakan beberapa tahap dengan mengikutsertakan kelompok mitra secara langsung. Lebih rinci masing-masing tahapan diuraikan pada penjelasan berikut.

1) Tahap Sosialisasi

Tahap ini dilakukan setelah tahap persiapan selesai. Kegiatan yang dilakukan yaitu mengadakan pertemuan dengan masyarakat yang akan mengikuti kegiatan pelatihan pembuatan desinfektan berbahan dasar alami dan ramah lingkungan sebagai bentuk pencegahan penyebaran Covid-19. Pertemuan ini dilakukan untuk menyampaikan pandangan dan sekaligus meminta ijin untuk melakukan kerja sama dalam kegiatan pelatihan ini. Kegiatan ini dilakukan beberapa kali untuk memastikan kegiatan yang akan dilakukan diterima oleh kelompok mitra.

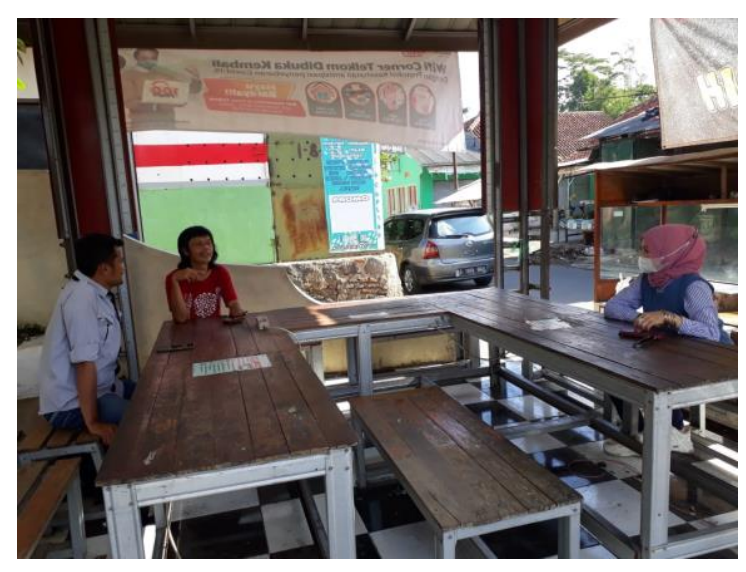

Gambar 2. Sosialisasi dengan Kelompok Mitra

2) Tahap pelaksanaan

Tahap pelaksanaan dilakukan dengan kegiatan sebagai berikut.

a. Penyampaian materi dan demo pembuatan desinfektan

Kegiatan ini dilakukan pada 19 September 2021 dengan menerapkan protokol kesehatan. Kegiatan yang dilakukan yaitu masyarakat sasaran bersama kelompok mitra menerima materi peningkatan kesadaran dan kewaspadaan dalam menghadapi pandemi Covid-19 melalui peningkatan penerapan $5 \mathrm{M}$; langkahlangkah pembuatan desinfektan berbahan dasar alami dan ramah lingkungan; serta demo/praktek pembuatan desinfektan dengan langkah-langkah yang telah disampaikan. Kegiatan praktek yang dilakukan diterima dengan baik sehingga 
kelompok sasaran dengan aktif mengikuti proses diskusi hingga praktek secara langsung.

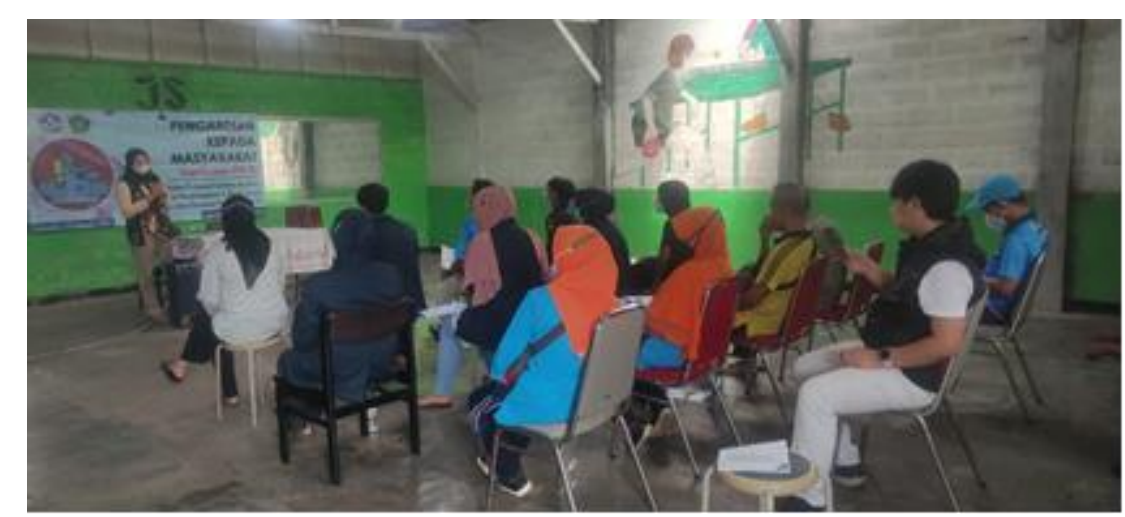

Gambar 3. Kegiatan penyampaian materi

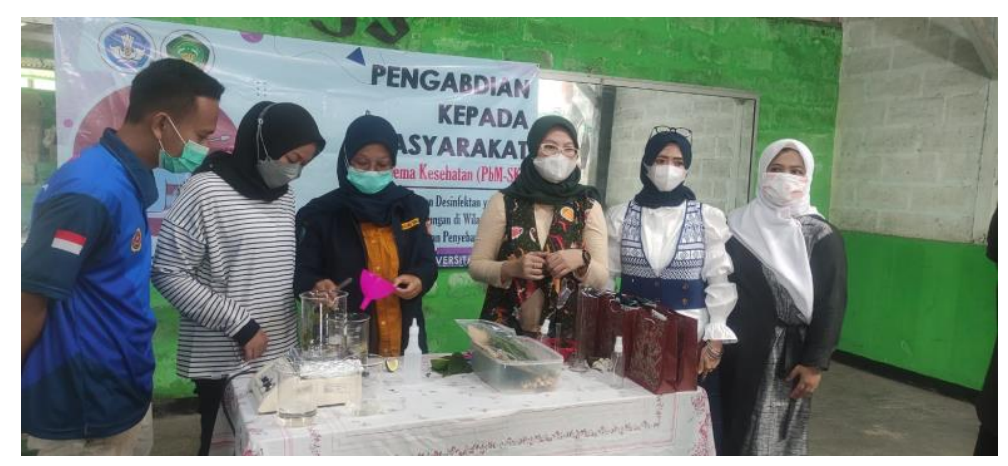

Gambar 4. Demo pembuatan desinfektan

b. Pembagian masker, desinfektan dan sembako.

Pembagian masker, desinfektan dan sembako kepada kepada masyarakat sasaran sebagai sarana penguatan kesadaran masyarakat terhadap prokes untuk mencegah dan menghambat persebaran Covid-19. Kegiatan ini dilakukan sebelum penutupan pelatihan berlangsung.

3) Tahap Evaluasi

Tahap evaluasi dilakukan dengan membagikan angket yang diisi oleh peserta pelatihan dan dikembalikan setelah acara pelatihan berakhir. Kegiatan evaluasi bertujuan mengetahui keberlanjutan komitmen pembuatan desinfektan berbahan aman dan ramah lingkungan secara konsisten oleh masyarakat mitra. Ini sebagai bentuk penilaian keberhasilan program yang dilakukan.

Berdasarkan hasil temuan data di lapangan baik melaui pengamatan langsung maupun melalui angket yang telah diisi oleh peserta pelatihan, kegiatan pelatiahan berjalan dengan baik dan penerimaan masyarakat sangat positif. Hal ini dibuktikan dengan hasil pengamatan proses diskusi dan demo pembuatan disinfektan yang menunjukkan 
bahwa masyarakat mitra sangat aktif selama kegiatan. Ini linier dengan jawaban angket yang telah diisi oleh peserta pelatihan, yaitu kelompok masyarakat mitra.

Masyarakat merasa sangat puas dengan kegiatan pelatihan dengan prosentase $79 \%$ menjawab sangat puas dan $11 \%$ menjawab puas. Hal ini dikarenakan kegiatan pelatiahn yang diberikan oleh Tim Pengabdian Masyarakat Universitas Siliwangi sesuai dengan harapan masyarakat. Sebanyak 70\% masyarakat setuju dan 30\% sangat setuju bahwa kegiatan pelatihan ini sesuai harapan mereka. Selain itu, 81\% masyarakat menyatakan sangat setuju jika pelatihan yang diberikan sesuai dengan kebutuhan mereka di masa pandemi Covid-19. 19\% lainnya menyatakan setuju dengan pelatihan yang diberikan sebab pelatihan tersebut memberikan edukasi untuk membuat disinfectan dari bahan alami yang mudah mereka temukan di sekitar rumah.

Keaktifan masyarakat diakui sebagai bentuk kritis dalam merespon materi yang diberikan. 89\% masyarakat menyatakan bahwa mereka sangat antusias dalam bertanya sehingga mereka dapat menemukan solusi dari permasalahan yang ditanyakan seputar pembuatan disinfektan. Hal ini kemudian direspon oleh masyarakat dengan antusisas yaitu sebanyak 90\% setuju adanya tindak lanjut dari kegiatan pelatihan ini pada waktu berikutnya. Bahkan ada msyarakat yang menyampaikan pendapat agar tim pengabdian masyarakat Universitas Siliwangi dapat memberikan bentuk variasi pelatihan lainnya untuk meningkatkan kemampuan masyarakat.

\section{SIMPULAN}

Kegiatan pengabdian kepada masyarakat yang dilakukan oleh tim pengabdian masyarakat universitas siliwangi diterima dengan sangat baik oleh kelompok masyarakat mitra. Antusiasme masyarakat dalam menerima pemaparan materi dan kegiatan demo pembuatan disinfektan dengan bahan alami menjadi indikator pengabdian kepada masyarakat melalui kegiatan pelatihan pembuatan disinfektan dengan bahan alami berhasil dilakukan. Masyarakat menginginkan adanya tindak lanjut dari kegiatan pengabdian ini dan meberikan permintaan pelatiahan bengan tema lainnya. Ini menunjukkan masyarakat aktif dan memiliki potensi untuk berdaya. Dengan demikian diperlukan tindak lanjut kerja sama dengan tema kegiatan yang berbeda untuk meberdayakan masyarakat di lingkungan Awipari pada waktu beerikutnya.

\section{UCAPAN TERIMA KASIH}

Kelancaran dan kesuksesan kegiatan pengabdian kepada masyarakat melalui bentuk pelatihan pembuatan disinfektan berbahan alami tidak lepas dari dukungan berbagai pihak. Ucapan terimakasih kami sampaikan terutama kepada kelompok mitra yang telah bersedia menjalani kegiatan pelatihan dengan sangat baik dan memberikan waktu serta tempat untuk melaksanakan kegiatan pelatihan ini. Selain itu, ucapan terimakasih juga kepada Universitas Siliwangi melalui LPPM yang telah memberikan 
kesempatan dan dana hibah untuk melaksanakan kegiatan pengabdian kepada masyarakat ini.

\section{REKOMENDASI}

Kegiatan serupa perlu dilakukan kembali dengan waktu yang lebih lama dan pendampingan yang lebih intensif. Selain itu, saran pelatihan lainnya yang diusulkan oleh masyarakat juga perlu di pertimbangkan seperti pelatihan pembuatan handsanitizer berbahan alami dan pelatihan kewirausahaan. Pelatihan yang diusulkan tersebut menunjang kemampuan masyarakat untuk menghadapi dinamika/permasalahan selama masa pandemi berlangsung, terutama dalam penyediaan produk disinfektan yang ramah lingkungan.

\section{REFERENSI}

Budiman, B., Arisman, A. Y., Sulfidar, S., \& Arsyad, M. (2020). Pembuatan Disinfektan dari Bahan Alami untuk Meminimalisir Penularan Covid-19. Wellness And Healthy Magazine, 2(2), 211-218.

Pusat Informasi \& Koordinasi COVID-19. Sebaran Kasus Covid-19 di Jawa Barat. https://pikobar.jabarprov.go.id/distribution-case

Dharmawanti, R. D., Aprillia, B., Rahmawati, D., Alfiah, A., \& Pujiyant, A. (2021). Penyuluhan Cara Pembuatan Disinfektan Alami yang Ramah Lingkungan pada Majelis Ta'lim Khairunisa, Ciputat, Tangerang Selatan. Prosiding Dedikasi: Pengabdian Mahasiswa Kepada Masyarakat, 1(1), 90-99.

Hairunisya, N., \& Dkk. (2020). Pemberdayaan di Sektor Pariwisata Sebagai Upaya Meningkatkan Perekonomian Masyarakat. Jurnal Pengabdian Kepada Masyarakat, 26(4), 241-247.

Hariani, P. L., Said, M., \& Rohendi, D. (2021). Pelatihan Pembuatan Desinfektan dan Hand Sanitizer dengan Penambahan Aroma Alami sebagai Upaya Pencegahan Penularan Virus Covid-19. Abdi Insani, 8(2), 198-204.

Indrawati, W. (2020). Membantu Masyarakat Mencegah Wabah Covid-19. ADALAH, 4(1).

Nursofwa, R. F., Sukur, M. H., \& Kurniadi, B. K. (2020). Penanganan Pelayanan Kesehatan Di Masa Pandemi Covid-19 Dalam Perspektif Hukum Kesehatan. Inicio Legis Fakultas Hukum Universitas Trunojoyo Madura, 1(1).

Badan Pusat Statistik Kota Tasikmalaya. https://tasikmalayakota.bps.go.id

Wang. (2019). Pandemi COVID-19. https://id.wikipedia.org/wiki/Pandemi_COVID-19 